Формування регіональної політики співробітництва з міжнародними торгово-економічними організаціями в контексті децентралізації державного управління

Віктор Щербак, Дніпропетровський регіональний інститут державного управління Національної академії державного управління при Президентові України

У статті досліджується прихований вплив регіональної політики співробітництва на процеси розвитку трансформаційних країн. Метою статті $є$ встановлення особливостей формування регіональної політики співробітництва з міжнародними торгово-економічними організаціями в контексті децентралізації державного управління.

Проаналізовані завдання транскордонного співробітництва у контексті етнокультурних особливостей, а також інституційних і процесуальних передумов модернізації економічної співпраці на регіональному рівні. Представлено процеси консолідації неформальних центрів прийняття рішень як чинників збільшення числа дієвих представників політики співробітництва. Акцентовано увагу на економічному типі тієї чи іншої території, яка визначає трансрегіональну політику співробітництва та іiі провідних економічних акторів. Водночас наголошено на ознаках емпіричного підгрунтя регіональної політики співробітництва 3 міжнародними економічними організаціями.

Підкреслено невідповідність основних секторів економічної участі та критеріїв дієвості політики міжрегіонального співробітництва 3 міжнародними економічними організаціями. На основі проведеного аналізу розкрито бюрократичну та менеджерську тенденції розвитку регіональної політики транскордонного співробітництва в сучасній Україні та напрямки iï еволюції. Визначено, що бюрократична та менеджерська тенденції розвитку регіональної політики транскордонного співробітництва також є одним з об'єктивних критеріїв оцінки напрямку іï еволюції та іï прогресивного чи регресивного стану. Аналіз інституційних важелів довів, що в умовах соціально-економічної трансформації офіційні посадові особи вищого рівня можуть не входити до складу державних інститутів, які є відповідальними за вироблення регіональних політик співробітництва.

Ключові слова: регіональна політика співробітництва, нормативно-правове забезпечення, державне управління, державна стратегія планування, економічні актори

\title{
Regional policy for cooperation with international trade-economic organizations formation in the context of government decentralization
}

\section{Viktor Scherbak, Dnipropetrovsk Regional Institute for Public Administration National Academy for Public Administration under the President of Ukraine}

The article examines the hidden influence of regional cooperation policy on the processes of development of transformation countries. The purpose of the article is to determine the peculiarities of forming a regional policy of cooperation with international trade and economic organizations in the context of decentralization of public administration.

The tasks of cross-border cooperation in the context of ethno-cultural peculiarities, as well as institutional and procedural prerequisites for modernization of economic cooperation at the regional level are analyzed. The processes of consolidation of informal decision-making centers as factors of increasing the number of effective representatives of cooperation policy are presented. 
Attention is drawn to the economic type of the territory, which determines the trans-regional policy of cooperation and its leading economic actors. At the same time, it emphasized the features of the empirical basis of regional policy of cooperation with international economic organizations.

The discrepancy between the main sectors of economic participation and the criteria for the effectiveness of the policy of interregional cooperation with international economic organizations are emphasized. On the basis of the conducted analysis the bureaucratic and managerial tendencies of development of regional policy of cross-border cooperation in modern Ukraine and directions of its evolution are revealed. It is determined that the bureaucratic and managerial tendencies of the development of regional policy of cross-border cooperation are also one of the objective criteria for evaluating the direction of its evolution and its progressive or regressive state. The analysis of institutional levers has shown that in the conditions of socio-economic transformation, high-level officials may not be part of the state institutions responsible for developing regional cooperation policies.

Keywords: regional cooperation policy, regulatory support, public administration, state planning strategy, economic actors

\section{Формирование региональной политики сотрудничества с международными торгово-экономическими организациями в контексте децентрализации государственного управления}

\section{Виктор Щербак, Днепропетровский региональный институт государственного управления Национальной академии государственного управления при Президенте Украины}

В статье исследуется скрытое влияние региональной политики сотрудничества на процессы развития трансформационных стран. Целью статьи является установление особенностей формирования региональной политики сотрудничества с международными торгово-экономическими организациями в контексте децентрализации государственного управления.

Проанализированы задачи трансграничного сотрудничества в контексте этнокультурных особенностей, а также институциональных и процессуальных предпосылок модернизации экономического сотрудничества на региональном уровне. Представлены процессы консолидации неформальных центров принятия решений как факторов увеличения числа действующих представителей политики сотрудничества. Акцентировано внимание на экономическом типе той или иной территории, определяет трансрегиональные политику сотрудничества и ее ведущих экономических актеров. В то же время отмечено признакам эмпирического основания региональной политики сотрудничества с международными экономическими организациями.

Подчеркнуто несоответствие основных секторов экономического участия и критериев действенности политики межрегионального сотрудничества с международными экономическими организациями. На основе проведенного анализа раскрыто бюрократическую и менеджерскую тенденции развития региональной политики трансграничного сотрудничества в современной Украине и направления ее эволюции. Определено, что бюрократическая и менеджерская тенденции развития региональной политики трансграничного сотрудничества также является одним из объективных критериев оценки направлении ее эволюции и ее прогрессивного или регрессивного состояния. Анализ институциональных рычагов доказал, что в условиях социально-экономической транс86 
формации официальные должностные лица высшего уровня могут не входить в состав государственных институтов, ответственных за выработку региональных политик сотрудничества.

Ключевые слова: региональная политика сотрудничества, нормативно-правовое обеспечение, государственное управление, государственная стратегия планирования, экономические актеры

\section{Постановка проблеми}

7 еоретико-методологічні засади вивчення вітчизняного та зарубіжного досвіду формування регіональної політики співробітництва показали необхідність застосування міждисциплінарного підходу як для встановлення динамічних характеристик функціонування регіональних політики співробітництва, так і для окреслення їх внутрішньо-системної взаємодії. Перехід сучасної науки державного управління до проблем комплексного вивчення транскордонного співробітництва на основі аналізу статистичних даних та індексів розвитку, показав, що поряд з формальними та нормативними чинниками впливу на внутрішньоекономічну ситуацію в кожній країні, що проходить період трансформації, наявна група внутрішніх чинників, які не можуть бути повною мірою визначені як наслідок функціонування формальних інституцій, або інституцій, які традиційно включені до складу політичних систем. Феномен прихованого впливу регіональної політики співробітництва на процеси розвитку трансформаційних країн був вперше встановлений на тлі процесів політичної модернізації у країнах Південно-Східної Азії, а також поставторитарного розвитку країн Південно-Східної Свропи у 90-ті роки XX століття та на початку XXI століття. В подальшому цю методологічну матрицю намагалася застосувати до розкриття специфіки регіональних політик співробітництва інших посткомуністичних держав.

Саме в цей період 3'явилися такі критерії оцінювання регіональної політики співробітництва як адаптивність, динамізм, внутрішня консолідація, механізми рекрутування економічних гравців. Важливими параметрами стали також ступінь демократизму, зв'язок з механізмами економічного лідерства та роль рушій- них сил модернізації. Водночас специфіка транскордонного співробітництва посткомуністичного типу принесла низку коректив, які стосувалися не лише етнокультурних особливостей, але й інституційних і процесуальних передумов модернізації економічної співпраці на регіональному рівні. Управлінські засади регіональної політики співробітництва в усьому світі мали тенденції до збереження замкненості кола власнків та зовнішньої мімікрії щодо нових інституційних змін та стрімкого опанування неформальними практиками управління регіональними процесами. Такі тенденції стали своєрідною паралельною системою управління транскордонною економічною співпрацею на рівні регіонів.

На тлі пострадянських держав особливо проявився принцип консервації неформальних та непублічних практик регіональної політики співробітництва, які були пов'язаний з консервацією відносин економічної взаємодії на рівні регіонів. Гальмування процесів ринкових реформ, збереження систем тіньової економіки потребували нового істотного підходу для аналізу внутрішньо-регіональних економічних відносин. В даній предметній сфері таким підходом став кластерний аналіз, який дозволив виявити особливості формування економічних відносин та горизонтальних економічних зав'язків на рівні регіонів. Суб'єктно-орієнтований підхід дозволив виявити особливості регіонального управління за допомогою політики співробітництва 3 міжнародними економічними організаціями не на основі формальної належності до управлінських інститутів, а на основі реального впливу на специфіку розвитку регіонів.

\section{Аналіз публікацій}

Наукове обгрунтування регіональної політики щодо співпраці з міжнародними економічними організаціями в Україні 
є недостатнім. Ця проблема викликала цікавість таких вітчизняних науковців, як I. Бакаєва [1], В. Микитенко та О. Гребенюк [3], Т. Сергієнко [4]. Серед зарубіжних науковців тема менеджменту регіональної співпраці привернула увагу Дж. Гілберта та Н. Банік [7], С. Лавенекс [11]. Здебільшого питання регіональної політики співробітництва науковцями розглянуто в контексті інтенсифікації розвитку суміжних територій та покращення наднаціонального врядування територіальними одиницями. Однак, на сучасному етапі нерозробленою раніше частиною проблеми, порушеною у даній статті, є вивчення специфіки інституціонального та соціокультурного підгрунтя системи вироблення державно-управлінських рішень у рамках політики співпраці на рівні регіонів.

Метою статті $\epsilon$ встановлення особливостей формування регіональної політики співробітництва 3 міжнародними торгово-економічними організаціями в контексті децентралізації державного управління.

\section{Основний зміст}

Сучасні розробки державного управління формують враження стосовно динаміки розвитку регіональної політики співробітництва як суб'єктів регіонального розвитку в межах двох методологічних полюсів. Першим $є$ вимір діяльності політики співробітництва та його відповідність параметрам та вимогам демократичного економічного реформування. Другим є дієвість та ефективність (результативність) регіональної політики співробітництва. В межах цих двох парадигмальних фокусів розвиваються спроби вмонтувати регіональну політику економічного співробітництва до системологічної картини загального транскордонного співробітництва. Водночас, на думку автора, підкріплену матеріалами дослідження регіональні політики співробітництва у різних країнах сучасного світу (див. [10]), вироблення основ менеджменту регіональної міжнародної співпраці на сучасному етапі виступають самостійним, динамічним феноменом. Він характеризується високим ступенем 88 адаптивності внутрішньої збалансованості та тенденцією до самозбереження i відстоювання своїх інтересів. Зазначені процеси мають подвійну динаміку завдяки умовам децентралізації нормативно-правового регулювання та спроби комплексного контролю над ситуацією в регіонах $з$ боку центральних інституцій політики співробітництва.

Розкриття змісту функціональності регіональної політики співробітництва у рамках транскордонного співробітництва було пов'язане з такими ключовими чинниками як потреби регіонів, зміст політичних перетворень, необхідність поглиблення та підвищення темпів економічного зростання. У сучасній літературі, яка ідентифікує наявність регіональних політичних політики співробітництва не лише у пострадянських, але й постколоніальних умовах, визначення функцій регіональної політики співробітництва здійснюється на основі нормативізму (див. [9]). Однак, приписування якостей ідеалістичного характеру політики співробітництва $\epsilon$ певною хибною позицією, оскільки реальний стан і конфігурація функціонування регіональних політики співробітництва має інший, більш реалістичний зміст та значення. Індуктивний підхід у визначенні наявного стану регіональнј] політики співробітництва також дає змогу побачити нормативістські негативні відхилення від еталонного західного процесу публічного менеджменту економічних процесів.

Ідентифікація корумпованості, клановості, консерватизму та ретроградності окремих регіональних підходів до політики співробітництва формує своєрідний полюс протиріч та очікувань від політики співробітництва, які своєю чергою за циклічним принципом формують масу вимог, які не мають реалістичного характеру. На думку автора, розгортання мережі нормативістських позицій стосовно сучасних різновидів регіональної політики транскордонного співробітництва повинно брати до уваги неусталеність соціокультурного тла нормативістських вимог (див.[8]). Нігілістичні настрої окремих 
економічних акторів перехідних держав, а також суб'єктивізм в оцінці центральної політики регіонального співробітництва, формують ситуацію низького рівня легітимності. Загалом ситуація в Україні та інших перехідних країн Східної Свропи (зокрема, Албанії, Північної Македонії, Болгарії тощо [6]) характеризується частою зміною функцій регіональних політик співробітництва.

На сучасному етапі виникає можливість визначити три основні напрямки оцінки функціональності політики співробітництва регіональних економічних спільнот та міжнародних економічних організацій. Цими напрямками є функції політики співробітництва між регіональними адміністративно-територіальними одиницями та міжнародними організаціями. По-перше, це функція консолідації, яка полягає у концентрації навколо центрів державного управління економічним розвитком, або неформальних центрів прийняття рішень як найбільшого числа дієвих представників політики співробітництва, в тому числі бізнесового та культурного характеру. Ця функція визначає формування неформальної програми умов та правил гри на регіональному економічному ринку та у відносинах 3 регіональними економічними об'єднаннями (наприклад, Організацією Об'єднаних Націй із промислового розвитку, Економічної і соціальної комісії для Азії і Тихого океану, Економічної комісії для Латинської Америки і Карибського басейну, Економічної комісії для Африки тощо). Другою функцією є забезпечення лояльності та адаптивності щодо загальнонаціонального економічного процесу. Отже, можливість прозорих каналів для контакту 3 центральними інститутами співробітництва та виконання їх функції i розпоряджень в межах міжнародної патрон-клієнтарної системи, або в межах системи рівного економічного взаємообміну. В умовах, коли ці важливі функції залишаються нереалізованими, регіональні політики співробітництва швидко втрачають контроль над ситуацією, інституційна єдність зменшується, виникають «контр- політики» регіонального співробітництва. Істотного значення набуває група функцій, пов'язаних 3 критеріями ефективності політики співробітництва, або виконання ними певної позитивної діяльності 3 конкретним результатом. Ці функції включають широке коло завдань, які висуваються до органів управління на регіональному і місцевому рівні. Серед іншого, це відповідальність за соціально-економічний розвиток та саме в цих функціях відповідальності та технічного контролю над ситуацією в середині регіону мають прояв оцінки пасіонарності політики співробітництва та їх спроможності [12]. Важливими $є$ і зовнішні функції політики співробітництва, серед яких чільне місце посідають функції арбітражу між місцевими та центральними економічними акторами, функції культурного, регіонального та соціального лідерства, функції розподілу надлишкового продукту та прибутків у межах певних територій [12].

Зазначені функції в умовах соціально-економічної трансформації $є$ актуальними в силу того, що центральна влада нерідко втрачає контроль над периферійними територіями, надаючи можливість регіональним політикам співробітництва самим виявляти ініціативу щодо впорядкування ситуації на місцях. До цього рівня функціоналу регіональних політики співробітництва в сучасний період слід зараховувати також функції регіонального соціального та економічного планування, які формують основи місцевого та регіонального інноваційного розвитку та управлінської ідентичності.

В умовах сучасної України та інших пострадянських держав, трансрегіональна політика співробітництва та сукупність економічних акторів уособлюють, до певної міри, певний економічний тип тієї, чи іншої території [5]. Навіть, якщо вона не має істотних етнокультурних відмінностей 3 рештою території, вносять внесок у формування економічного світогляду та управлінської самосвідомості.

У межах практики взаємодії з міжнародними фінансовими організаціями (зо- 
крема, МВФ, СБРР) тощо, успішного підтвердження набула схема обгрунтування економічної суб'єктності міжрегіональної політики співробітництва [4]. Вона була розвинена на основі уваги до відносно автономних рішень регіонального економічного співробітництва в ординарних та кризових ситуаціях.

У залежності від результатів самодостатньої діяльності суб' єктів регіональної політики співробітництва виокремилися три основні виміри її прояву. Насамперед, це формування економічних інститутів, самостійне тлумачення реформ центрального рівня та самодостатність у контролі над регіональними, політичними, соціальними і економічними активами.

Показником самодостатності та суб'єктності регіональних політик транскордонного співробітництва посткомуністичного типу стало включення регіональних політичних суб' єктів до загального проекту ринкової лібералізації та перетворення окремих компаній та галузей на тих напрямках, які постійно перебувають на регіональному рівні та не прагнуть переходу на центральний рівень. Також виключної ваги набувають тенденції неформального встановлення економічного домінування з метою відстоювання власних інтересів.

Також показником демократичної зрілості регіональних політичних політик співробітництва, завершення процесу трансформації є включеність регіональної політики співробітництва до динамічного процесу постійних змін регіональному співробітництві, який передбачає постійну внутрішню зміну реакції електорату на усунення неформальних практик тощо.

Особливості представницької функції підприємницької спільноти в межах діяльності міжрегіональної політики співробітництва знайшли втілення як у формуванні різних форм представництва в межах формальних органів державного управління та місцевого самоврядування, а також в межах комунікаційного представництва.

Включеність регіональних моделей політики співробітництва до практик 90 тіньової економіки та ухилення від сплати податків та моделей залежності в сучасних умовах стало індикатором консервування архаїчних політичних практик в межах певних територій. Водночас об'єктивні показники зростання економічної участі населення в укріпленні добробуту регіонів показали, що в умовах сучасного транскордонного співробітництва з системи контролю та володарювання на систему представництва в межах певної території. Тісно пов'язаною з цими процесами є економіко-комунікаційна функція регіональної політики співробітництва, яка має два вектори, - зовнішній - спрямований на трансляцію інтересів та ідентичності регіонального рівня назовні, в тому числі і на загально-національний рівень, $\mathrm{i}$ - внутрішній, який забезпечує внутрішню інтегрованість та спробу формування однорідної спільноти з представників регіональної політичної співробітництва. Чим більш складною та розгалуженою є система внутрішньорегіональної економічної комунікації всередині політики співробітництва, тим більш перспективною $є$ їх існування.

В межах сучасних процесів глобалізації знайшла своє підтвердження і гіпотеза щодо необхідності формування регіонального співробітництва своєрідного економіко-культурного коду, який потребує подальшої трансляції через канали міжнародної комунікації з метою як забезпечення внутрішніх потреб в існуванні регіональних економічних гравців, так і 3 метою окреслення меж із зовнішнім символьним середовищем.

Чим більш активною $є$ регіональна політика співробітництва в інформаційному полі, тим більш значущими $є$ iii позиції та можливості варіативної міжнародної підтримки. Разом з тим, у більшості пострадянських країн, включно і 3 Україною, зберігається периферійність мислення регіональних суб'єктів політики співробітництва та неможливість здобуття ними власного транснаціонального економічного профілю, відокремленого від центрального рівня [2].

Процес розробки регіональної концеп- 
ції співпраці 3 такими організаціями, як Свропейська асоціація вільної торгівлі, Європейська економічна зона, Середземноморський союз, Трансатлантичне торговельне та інвестиційне партнерство, є життєво-важливим для виживання суб'єктів регіональної політики співробітництва. Вертикальне просування в умовах децентралізації $€$ досить сумнівним, а збереження контролю над економічними активами прямо пов'язане 3 контролем над органами місцевого самоврядування та державного управління.

Емпіричні показники регіональної політики співробітництва в умовах ринкових ліберальних трансформацій спираються на різний кількісний склад економічних акторів. Зокрема, йдеться про кількість та якість кадрового резерву, наявність осіб з відповідною профільною освітою. Водночас, кількісний підхід має декілька вад в умовах мінливих глобальних економічних перетворень. Ними є: невідповідність кількісного складу компаній, асоціацій підприємців, що не дозволяє повною мірою розглядати ідеологічні та ціннісні переваги регіональних політик співробітництва. Важливою ознакою емпіричного підгрунтя дослідження регіональної політики співробітництва $є$ невідповідність основних секторів економічної участі та критеріїв дієвості політики міжрегіонального співробітництва [5].

Слабке представництво громадських підприємницьких структур у регіональній політиці співробітництва не відповідає основним засадам структурних елементів регіональної політики співробітництва країн ЄC. Зв'язок між регіональними політичними відносинами та дієвими персоналіями регіональних політики співробітництва подекуди мають суто формальний зміст та характер, який фіксується на основі посадових інструкцій та обов'язків.

Динамічні характеристики розвитку регіональних політик співробітництва також потребують окремого вивчення в межах системних характеристик регіональних економічних режимів. Фактичний стан регіональних політичних політики співробітництва відповідає на питання специфіки взаємодії державних владних структур та громадянського суспільства. Динаміка регіональних політик співробітництва $є$ параметром, який відображає зміну складу політики співробітництва за певний період часу i, зазвичай, прив'язується до електоральних циклів.

\section{Висновки}

Таким чином, динаміка формування регіональної політики співробітництва може розглядатися також і 3 точки зору внутрішньої динаміки економіки регіонів. Це стосується зміни центральних і периферійних компонентів. Так, на прикладі низки регіонів України можна спостерігати, що провідну роль у процесах прийняття рішення в державно-владних структурах в період функціонування урядів А. Яценюка та В. Гройсмана відігравали різні економічні групи. Вони концентрувалися навколо посадових діючих осіб рівня губернатора та керівника обласної ради. Фаховість кадрового забезпечення посадових осіб на рівні регіонів мала вторинний характер. Динаміка зміни регіональної політики співробітництва в умовах кризових станів транскордонного співробітництва чітко демонструє їх детермінованість макроекономічними процесами центрального рівня. Особливо наочно це видно на основі аналізу діяльності політики співробітництва конкретних областей України в умовах проведення АTO - OOC.

Бюрократична та менеджерська тенденції розвитку регіональної політики транскордонного співробітництва також $\epsilon$ одним з об'єктивних критеріїв оцінки напрямку її еволюції тієї її прогресивного чи регресивного стану. Аналіз інституційних важелів довів, що в умовах соціально-економічної трансформації офіційні посадові особи вищого рівня можуть не входити до складу державних інститутів, які $є$ відповідальними за вироблення регіональних політик співробітництва. Перспективою подальшої розробки теми, порушеної у даній статті, є вивчення особливостей регіональних політик співробітництва країн сучасного $\mathrm{CC}$, які нещодавно набули статусу країн-членів. 


\section{БІБЛІОГРАФІЧНІ ПОСИЛАННЯ}

1. Бакаєва І. Г. Глобальне фінансове управління та регіональне співробітництво. Науковий вісник Академії муніципального управління. Серія: Економіка. 2011. Вип. 9. С. 63-69.

2. Зубченко Н. І. Регіональне (не-європейське) співробітництво держав в сфері добробуту тварин та захисту їх від жорстокого поводження. Правова держава. 2014. № 17. С. $102-106$.

3. Микитенко В. В. Регіональне співробітництво та ущільнення виробничо-господарської взаємодії в Україні: розбудова каскадних форм регіональних соціально-економічних систем. Економіка. Управління. Інновації. 2015. № 2. URL: http://nbuv.gov.ua/UJRN/eui_2015_2_12.

4. Сергієнко Т. С. Регіональна політика країн Вишеградської групи у становленні прикордонної та міжрегіональної співпраці з Україною. Науковий вісник Ужгородського університету. Серія: Історія. 2012. Вип. 29. C. $42-48$.

5. Ткачук Л. М. Регіональне співробітництво як чинник розвитку туризму в Південно-Східній Азії. Економічна та соціальна географія. 2013. Вип. 3. С. 201-208.

6. Moraliyska M. Regional Economic Cooperation in the Western Balkans and Its Impact on Bulgaria. Economic Alternatives. 2015. Issue 1. P. 100-117.

7. Gilbert J., Banik N. Socio-economic impacts of regional transport infrastructure in South Asia. Infrastructure for Asian Connectivity. Edward Elgar Publishing, 2012. P. 139-163.

8. Ashima G. Payment Systems to Facilitate South Asian Intraregional Trade. Development Papers. United Nations Economic and Social Commission for Asia and the Pacific (ESCAP) South and South-West Asia Office, 2014. URL: https://ideas.repec.org/p/eap/sswadp/dp1403.html.

9. Bhattacharyay B. N., Kawai M., Nag R. M. Infrastructure for Asian Connectivity. Asian Development Bank Institute and Asian Development Bank, 2012. URL: http://hdl.handle.net/11540/126.

10. Prospects for Regional Cooperation on Cross-Border Electricity Trade in South Asia'. Background Paper SARI/ EI Programme. New Delhi, Integrated Research and Action for Development, 2013. URL: https://sari-energy.org/wpcontent/uploads/2016/03/Prospects-for-Regional-Cooperation-CBET-2013.pdf.

11. Lavenex S. EU External Governance in "Wider Europe”. Journal of European Public Policy. 2004. 11(4). P. 680-700.

12. Weber K., Smith M. E. Governing Europe's Neighbourhood. Partners or Periphery? New York : Manchester University Press, 2008. 346 p.

\section{REFERENCES}

1. Bakaieva, I. H. (2011). Hlobalne finansove upravlinnia ta rehionalne spivrobitnytstvo [Global Financial Management and Regional Cooperation]. Naukovyi visnyk Akademii munitsypalnoho upravlinnia. Seriia: Ekonomika - Scientific Bulletin of the Academy of Municipal Administration. Series: Economics, 9, 63-69 [in Ukrainian].

2. Zubchenko, N. I. (2014). Rehionalne (ne-yevropeiske) spivrobitnytstvo derzhav v sferi dobrobutu tvaryn ta zakhystu yikh vid zhorstokoho povodzhennia [Regional (non-European) cooperation of States in the field of animal welfare and protection against ill-treatment]. Pravova derzhava - Constitutional State, 17, 102-106 [in Ukrainian].

3. Mykytenko, V. V. (2015). Rehionalne spivrobitnytstvo ta ushchilnennia vyrobnycho-hospodarskoi vzaiemodii v Ukraini: rozbudova kaskadnykh form rehionalnykh sotsialno-ekonomichnykh system [Regional cooperation and consolidation of industrial-economic cooperation in Ukraine: development of cascading forms of regional socioeconomic systems]. Ekonomika. Upravlinnia. Innovatsii - Economics. Management. Innovation, 2. Retrieved from http://nbuv.gov.ua/UJRN/eui_2015_2_12 [in Ukrainian].

4. Serhiienko, T. C. (2012). Rehionalna polityka krain Vyshehradskoi hrupy u stanovlenni prykordonnoi ta mizhrehionalnoi spivpratsi z Ukrainoiu [Visegrad Group Regional Policy on Border and Interregional Cooperation with Ukraine]. Naukovyi visnyk Uzhhorodskoho universytetu. Seriia: Istoriia - Scientific Herald of Uzhhorod University. Series: History, 29, 42-48 [in Ukrainian].

5. Tkachuk, L. M. (2013). Rehionalne spivrobitnytstvo yak chynnyk rozvytku turyzmu v Pivdenno-Skhidnii Azii [Regional cooperation as a factor in tourism development in Southeast Asia]. Ekonomichna ta sotsialna heohrafiia, 3, 201-208 [in Ukrainian].

6. Moraliyska, M. (2015). Regional Economic Cooperation in the Western Balkans and Its Impact on Bulgaria. Economic Alternatives, 1, 100-117.

7. Gilbert, J., \& Banik, N. (2012). Socio-economic impacts of regional transport infrastructure in South Asia. Infrastructure for Asian Connectivity. (pp. 139-163). Edward Elgar Publishing.

8. Ashima, G. (2015). Payment Systems to Facilitate South Asian Intraregional Trade. Development Papers. United 
Nations Economic and Social Commission for Asia and the Pacific (ESCAP) South and South-West Asia Office. Retrieved from https://ideas.repec.org/p/eap/sswadp/dp1403.html.

9. Bhattacharyay, B. N., Kawai, M., \& Nag, R. M. (2012). Infrastructure for Asian Connectivity. Asian Development Bank Institute and Asian Development Bank. Retrieved from http://hdl.handle.net/11540/126 .

10. Prospects for Regional Cooperation on Cross-Border Electricity Trade in South Asia'. (2013). Background Paper SARI/EI Programme. Integrated Research and Action for Development, New Delhi. Retrieved from https://sarienergy.org/wp-content/uploads/2016/03/Prospects-for-Regional-Cooperation-CBET-2013.pdf.

11. Lavenex, S. (2004). EU External Governance in "Wider Europe". Journal of European Public Policy, 11(4), 680-700.

12. Weber, K., \& Smith, M. E. (2008). Governing Europe's Neighbourhood. Partners or Periphery? New York: Manchester University Press.

\section{Щербак Віктор Михайлович}

Докторант

Дніпропетровський регіональний .. інститут державного управління Національної академії державного управління при Президентові України 49044, Дніпро, вул. Гоголя, 29

Email: viktor.scherbak75@ukr.net

\section{Scherbak Viktor}

Doctoral Candidate

Dnipropetrovsk Regional Institute for Public Administration National Academy for Public Administration under the President of Ukraine 29, Gogol Str., Dnipro, 49044, Ukraine

Цитування: Щербак В. М. Формування регіональної політики співробітництва з міжнародними торгово-економічними організаціями в контексті децентралізації державного управління. Аспекти публічного управління. 2019. Т. 7, № 11 . С. 85-93.

Citation: Scherbak, V.M. (2019). Formuvannia rehionalnoi polityky spivrobitnytstva z mizhnarodnymy torhovo-ekonomichnymy orhanizatsiiamy v konteksti detsentralizatsii derzhavnoho upravlinnia [Regional policy for cooperation with international trade-economic organizations formation in the context of government decentralization]. Public administration aspects, 7 (11), 85-93. 